\title{
Investigating the effects of customized cognitive fitness classroom on students' physics achievement and integrated science process skills
}

Chan, Joefrey R.

Dominican School, Manila, Philippines (jupri_4@live.com)

Morales, Marie Paz E.

Philippine Normal University, Philippines (morales.mpe@pnu.edu.ph)

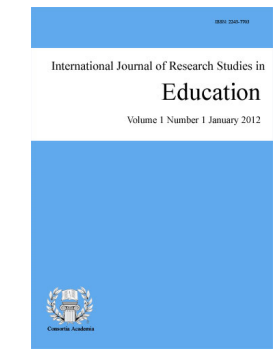

ISSN: 2243-7703 Online ISSN: 2243-7711

OPEN ACCESS

Received: 20 September 2016

Revised: 3 October 2016

Available Online: 19 October 2016

DOI: $10.5861 /$ ijrse. 2016.1648

Accepted: 14 October 2016

\section{Abstract}

Cognitive fitness, a product of neuroscience research that offers activities that fits how the brain learns best may offer insights to students' learning of science concepts. The study critically explored the effect of customized cognitive fitness classroom activities on the academic achievement of students in physics and their integrated science process skills (ISPS). Descriptive research design and qualitative approaches determined pertinent data from a purposively selected intact class of 43 grade niners in a government-supervised school in the Philippines' capital city. Results revealed that customized cognitive fitness classroom activities effectively and significantly improved student physics achievement and their ISPS. Students perceived the integration of customized cognitive fitness classroom activities in the learning process as something that made them feel relaxed, focused, reflective, and assimilative. Few among the students, however, feel distracted during the teaching and learning process with particular cognitive fitness activities (e.g. silence and collaborative activities). Based on the gathered data and results, it can be recommended that customized cognitive fitness classroom activities as a strategy to brain-based learning could be continuously utilized and intensified in classroom settings to enhance the $21^{\text {st }}$ century skills of students.

Keywords: cognitive fitness; brain-based learning; physics achievement; integrated science process skills 


\section{Investigating the effects of customized cognitive fitness classroom on students' physics achievement and integrated science process skills}

\section{Introduction}

At the turn of the century, the world community started evolving into a new era known as knowledge era (Turiman, Omar, Daud \& Osman, 2011) or knowledge-based society and economy which seems to drive better economic growth, reduce poverty index, and provide better global indices for countries. In fact, the Asian Development Bank (ADB, 2014) reported that building such economies is the most suitable way of ensuring strong and long-term growth which, however, requires numerous necessities including quality education to support it all. This requirement (quality education) emphasizes the importance of information, creativity, and innovation to match the needed $21^{\text {st }}$ century skills (digital age literacy, inventive thinking, effective communication, and high productivity) to meet the knowledge-based societal demands (NCREL \& Metiri Group, 2003).

Accordingly, scientific literacy as one of the literacies that define $21^{\text {st }}$ century skills (NCREL, 2003) refers to the knowledge and understanding of the scientific concepts and processes required for personal decision-making, participation in civic and cultural affairs, and economic productivity. Apparently, success in learning science and in developing $21^{\text {st }}$ century skills in learners are gauged on students' scientific literacy- a major global goal of science education which countries aspire to enhance their economic growth and global indices (Australian Council for Educational Research, 2014; Fensham, 1985; Hobson, 2006; Tan, 2004). In fact, dela Cruz (2015) even emphasized that science education of today should aim for a support system that focuses on the understanding of the nature of science and its connection to society through the advancement of scientific literacy where real world challenges should engage students to think creatively, critically, and constructively (higher order thinking skills) to achieve quality science education geared to developing scientific literacy. Equally, Anderson (2002) found that students' science process skills are important in promoting scientific literacy.

In the same vein, Turiman, Omar, Daud, and Osman (2011) established that research skills must be acquired by students to promote higher order thinking skills and better cognition consequently leading to scientific literacy. Thus, it becomes significant to look into cognition and processes of assimilating science process skills to facilitate students' capability to determine scientific issues in the local or national level and help them formulate the scientific and technological information to address the issues. This shift in the learning process and in learning pursuits, spurred various learning models linked to cognition and science process skills, which may be investigated to transition from a horizontal perspective to a loop of knowledge that merge knowledge, application, and continuous contribution (Kamisah \& Neelavany, 2010).

Researchers (BouJaoude, 2002; Hazen, 2002; Özdem, Çavaş, \& Çavaş, 2010) looked into various efforts to achieve improved scientific literacy. These researchers already made marks in the prevailing pursuit. Others (Aparna \& Smita, 2014; Ramakrishnan \& Annakodi, 2013), however, would like to zero in to the root of cognition and scientific process skills through the workings of the brain, better known as brain-based learning. This category of learning is a student-centered approach based on the structure and function of the human brain (Akyurek, 2013; Tüfekçial \& Demirelb, 2009). Accordingly, brain-based learning emphasizes the meaningful learning instead of memorization, which means that the brain does not easily learn things that are not logical or meaningful and that structuring and constructing is important. In fact, Caine and Caine (1995) coerced that the natural tendency in the brain is the integration of information, thus, learning should be attributed to activities such as the use stories, complicated subjects, and metaphors in order to associate information and apprehension. Labriole (2010) even argued that popular activities like sports, mnemonics, chunking pieces, and film can spark students' interest and activate their neurons. 
Effects of cognitive fitness classroom on students' physics achievement and integrated science process skills

Healthy brain practices as emphasized in brain-based learning entail better academic achievement. In fact, literature (Bas, 2010; Duman, 2010; Gozuyesil \& Dikici, 2014) found that brain-based learning increased students' academic achievement. One strategy to brain-based learning is cognitive fitness-a product of neuroscience research that offers activities that fit how the brain learns best. It provides suitable experience that can exercise the brain properly. Gilkey and Kilts (2007) even asserted that the brain's alertness results from cognitive fitness, which they described as a state of optimized ability to reason, learn, plan, and adapt particularly enhanced by attitudes, lifestyles choices, and exercise. Apparently, a cognitively fit student can make better decisions, solve problems better, and be able to deal with change, and stress in a more successful way. Dweck (2006) called the brain's capacity to change and develop to accommodate new ideas and alternative perspectives as "growth mindset (Cheng, 2016), a belief that a person's intelligence, personal qualities, and abilities can grow and develop over time." Accordingly, Rouman (2006) claimed that this principle steamed from the concept of neuro-plasticity - a concept that the brain has elastic and non-permanent neural links and connections which may be altered and re-wired based on the ability of the person to change structure and function in response to the person's experience. With such ability of the brain to restructure when cognitively stimulated, the study focused on determining how effective cognitive fitness is in improving student achievement and integrated science process skills.

\subsection{Purpose of the Research}

The study generally determined the effect of cognitive fitness classroom activities on the academic achievement of students in Physics and in the development of their science process skills. Specifically, the study sought answers to the following questions:

$>\quad$ Is there a significant difference on the academic performance of students in Physics in terms of physics achievement and science process skills after engaging them in customize cognitive fitness classroom activities in specific fields as: a) environment-energizing activities (musical moments and novelty and surprise); b) attention-catching activities (breathing and voice); c) student-energizing activities (circle games and silence); and d) team/community building activities (getting to know/group challenges and just for fun)?

$>$ How do students perceive the use of customized cognitive fitness classroom activities?

\section{Literature Review}

\subsection{Student Achievement}

Student achievement is an essential factor in quality education. In fact, Research and Development Education (RAND) (2012) emphasized that there are many factors that could contribute to students' academic performance. It was even termed by Steinmayr, Meißner, Weidinger, and Wirthwein (2015) as a multifaceted construct composed of several learning domains, commonly indicated as the achievement or performance outcomes in subject areas such as reading, language arts, mathematics, science, and history. Moreover, Cunningham (2012) found that the child's experiences and situations, the quality of schools and educators, and many other factors affect academic achievement. Though many (e.g. Hussain \& Akhtar, 2013; Narmadha \& Chamundeswari, 2013; National Monitoring Study of Student Achievement [NMSSA], 2012; Taylor, Scotter, \& Coulson, 2007) strived to improve student achievement, specifically in science, others (Bas, 2010; Duman, 2010; Gozuyesil \& Dikici, 2014) saw the probability of enhancing student achievement through brain practices and brain-based learning approaches.

Apparently, researchers believed in the capability of growth mindset (Cheng, 2016) to improve student achievement particularly in science (e.g. physics): 1) by customizing teaching-learning procedure and classroom environments according to brain-based learning (Duman, 2010); 2) through enhanced attitude (Bas, 2010) and 
motivation (Akyurek, 2013) of students; and 3) appropriate and matched individual-environment interaction (Özgelen, 2012). Furthermore, Ozgelen related this cognitive enrichment to science process skills which accordingly supported students development of thinking, reasoning, inquiry, evaluation, problem solving skills and creativity—skills necessary to attain scientific literacy and be successful in the $21^{\text {st }}$ century.

\subsection{Science Process Skills}

Raj and Devi (2014) defined science process skills as the transmittable ability to emulate and show behaviors of scientist. These abilities help hasten the learning in the physical sciences, motivate students to think that learning on their own is their liability, guarantee meaningful participation of students, influence enduring learning of students, and make the students perform correct research process by behaving and reasoning like scientist. Accordingly, the National Association for Research in Science Teaching (NARST, 1990) classified science process skills as: 1) basic science process skills (predicting, measuring, classifying, and observing); and 2) integrated science process skills (ISPS) that includes determining and describing variables, gathering and converting data, devising tables of data and graphs, describing relationships between variables, explaining data, calibrating materials, recording data, constructing hypothesis, setting up investigations and obtaining conclusion and generalization. Modifications instituted by Lancour (2009) described the following Integrated Science Process Skills used in this study as 1) formulating hypothesis; 2) identifying of variables; 3) defining variables operationally; 4) describing relationships between variables; 5) designing investigations; and 6) organizing data in tables and graphs. Identified correlation of these skills to students' achievement (Baser \& Durmus, 2010) spurs identifying how brain-enriched activities may somehow develop these skills.

\subsection{Cognitive Fitness}

Accordingly, Simmonds (2014) developed few interventions from insights on neuroscience studies proven to have academic impact in classroom settings. Tracing back, Cohen (2006) pursued the same objective landing onto the idea that continuing favorable changes in the human brain results from challenging the brain through life experiences and activities, considered as mental stimulation that consequently produce new synapses or contact points between brain cells. Gilkey and Kilts (2007) formally developed and termed the intervention as cognitive fitness - a strategy that features how the brain should be properly exercised. Apparently, these authors suggested the following as an exercise for the brain to get fit: reading funny books; playing games; acting out or role-playing; finding what you are not learning; getting the most out of business trips; taking notes; trying new technologies; learning new instruments or language; and exercising. They also suggested the following steps to maintain an engaged and creative brain: use encountered experiences; focus on playing hard and enjoying; search for schema or pattern; and seek novelty and innovation. Furthermore, the Dana Alliance for Brain Initiatives, (2008) emphasized that social interaction, physical exercises, mind energizers, a brain-friendly diet, healthy sleep cycles, and handling stress are the fundamental healthy-brain practices that primarily describe cognitive fitness. Apparently, Saleh (2011) used these activities and found a significant development of student conceptual understanding of Newtonian physics.

In the same vein, Evanski (2009) presented that state-changing activities must be done during the teaching-learning process because the brain needs a continuous blood supply, which brings oxygen and nutrients to the brain. His devised classroom activities (energizing the environment, getting students' attention, energizing the students, and building teams and community) promoted changes in the brain that energize the students to properly gather blood with enough oxygen flowing to the brain.

Thus, those aforementioned cognitive fitness activities that condition the brain to work best may bring about better cognition consequently enhancing students' science process skills and student achievement (in physics) eventually leading to scientific literacy. Attaining scientific literacy would intensely help our learners to fully acquire $21^{\text {st }}$ century skills for them to thrive and succeed in this era. Though several literatures drove the same advocacies: brain-based learning, cognitive fitness, scientific literacy, and $21^{\text {st }}$ century skill, this study converge 
Effects of cognitive fitness classroom on students' physics achievement and integrated science process skills

all these themes and customized them for integration in physics classes. Apparently, this study contributes to the body of knowledge on brain-based learning for Filipinos_-an emerging research area in the Philippine education system.

\section{Methodology}

The current research utilized the descriptive-analytical design (quantitative and qualitative approaches in data collection and analysis) to come up with answers to the research problems presented. Table 1 presents the summary of the entire process of the study.

\section{Table 1}

Summary of Research Process

\begin{tabular}{llll}
\hline Focus of the Study & \multicolumn{1}{c}{ Participants } & \multicolumn{1}{c}{ Data Collection/ Instruments } & \multicolumn{1}{c}{ Data Analysis } \\
\hline $\begin{array}{l}\text { Stage 1: } \\
\text { Preliminaries }\end{array}$ & $\begin{array}{l}\text { Content experts } \\
\text { (physics and } \\
\text { psychology) }\end{array}$ & $\begin{array}{l}\text { Development of pre-test/post-test, } \\
\text { interview guide, anecdotal guide, and } \\
\text { journal logs guide questions }\end{array}$ & $\begin{array}{l}\text { Coding of suggestion } \\
\text { from the descriptive } \\
\text { content validation }\end{array}$
\end{tabular}

Development of customized cognitive

fitness classroom activities

Pre-test administration (achievement test and Integrated Process Skills Test)

\begin{tabular}{|c|c|c|c|}
\hline $\begin{array}{l}\text { Stage 2: Cognitive } \\
\text { Fitness } \\
\text { Implementation }\end{array}$ & $\begin{array}{l}\text { intact grade } 9 \\
\text { class of } 43 \\
\text { students }\end{array}$ & $\begin{array}{l}\text { Investigating the effects of customized } \\
\text { cognitive fitness in classroom activities on } \\
\text { students' physics achievement and } \\
\text { integrated science process skills(using } \\
\text { cognitive fitness activities, and journal } \\
\text { logs) } \\
\text { Determining students' perception on the } \\
\text { use of cognitive fitness in classroom } \\
\text { activities (using journal logs and interview } \\
\text { protocols }\end{array}$ & $\begin{array}{l}\text { Recording of } \\
\text { respondents' views and } \\
\text { perceptions towards } \\
\text { customized cognitive } \\
\text { fitness classroom } \\
\quad \text { activities } \\
\text { Frequencies and } \\
\text { averages } \\
\text { Recording and coding of } \\
\text { students' behaviors, } \\
\text { attitudes and interests; }\end{array}$ \\
\hline $\begin{array}{l}\text { Stage 3: Post } \\
\text { implementation }\end{array}$ & & $\begin{array}{l}\text { Post-test administration (achievement test } \\
\text { and Integrated Science Process Skills Test) }\end{array}$ & $\begin{array}{l}\text { Descriptive statistical } \\
\text { analysis } \\
\text { Pretest and posttest } \\
\text { statistical treatment } \\
\text { using t-test of dependent } \\
\text { means }\end{array}$ \\
\hline
\end{tabular}

\subsection{Participants of the Study}

Conveniently, chosen participants of the study included an intact grade 9 class of 43 student aged 15-16. The curricular program (K-12 Program) implementation in the school affiliation of one of the authors dictated the choice of these participants. Particularly, this curricular program follows the spiral progression for science subjects in which physics is the content area during the investigation.

\subsection{Instruments}

Forty seven-item achievement test in Physics consisted of collected items from various standardized test served as both the pre-test and post-test. Items correlated at .05 composed the final list of items after content validation of experts.

Standardized integrated science process skill test (Shive, 2002). A 32-item test on research skills: formulating hypothesis, identifying variables, defining variables operationally, describing relationships between 
Chan, J. R., \& Morales, M. P. E.

variables, designing investigations, and organizing data in tables and graphs.

Journal logs, interviews, and anecdotes consisted of questions and guides to deduce qualitative data from students such as their perceptions and views.

Customized Cognitive Fitness Classroom Activities. Evanski (2009) highly influenced the nature of customized cognitive fitness classroom activities in this study. The succeeding procedures describe the implementation of customized cognitive fitness classroom activities. A summary of these activities presented in Table 2 provides a holistic view of how cognitive fitness suits in the physics class.

Table 2

Summary of Classroom Activities

\begin{tabular}{|c|c|c|c|}
\hline Cognitive Fitness & Components & Classroom Activities & Physics Topics \\
\hline Environment-Energizing & $\begin{array}{l}\text { Music } \\
\text { Novelty and } \\
\text { Surprise }\end{array}$ & $\begin{array}{l}\text { Pop songs, classical, } \\
\text { upbeats and instrumental } \\
\text { Guessing game, cliff } \\
\text { hanger, accent day }\end{array}$ & $\begin{array}{l}\text { Projectile motion } \\
\text { Impulse and momentum } \\
\text { Mechanical energy and } \\
\text { conservation } \\
\text { Heat and temperature }\end{array}$ \\
\hline $\begin{array}{l}\text { Attention-catching } \\
\text { activities }\end{array}$ & $\begin{array}{l}\text { Breathing } \\
\text { Voice }\end{array}$ & $\begin{array}{l}\text { deep breathing and breath } \\
\text { and "ssssh..." activity } \\
\text { changing voice and } \\
\text { callbacks activity }\end{array}$ & $\begin{array}{l}\text { Projectile motion } \\
\text { Mechanical energy and } \\
\text { conservation } \\
\text { Heat and temperature }\end{array}$ \\
\hline $\begin{array}{l}\text { Student-energizing } \\
\text { activities }\end{array}$ & $\begin{array}{l}\text { Circle games } \\
\text { Silence }\end{array}$ & $\begin{array}{l}\text { What are you doing activity } \\
\text { Mime time }\end{array}$ & $\begin{array}{l}\text { Projectile motion } \\
\text { Heat and temperature }\end{array}$ \\
\hline $\begin{array}{l}\text { Team/community } \\
\text { building activities }\end{array}$ & Group challenges & Alphabet game & $\begin{array}{l}\text { Power generation, } \\
\text { transmission and distribution } \\
\text { Impulse and Momentum } \\
\text { Mechanical energy and } \\
\text { conservation } \\
\text { Heat and Temperature }\end{array}$ \\
\hline
\end{tabular}

Environment-energizing activities - Environment-energizing activities include tasks for musical moments and novelty and surprise. Playing music classed as instrumental, upbeat, pop songs, and classical maneuvered musical moment activities done during seat works. The participants experienced four genre of music: 1) pop songs; 2) classical music; and 3) upbeat songs; and 4) instrumental music.

Novelty and surprise activities include guessing games, cliff hanger questions, and accent day activity. Objects (e.g. big protractors, table tennis balls, loan tennis ball, and coins) placed in "mystery box" featured the "guessing game," used in the development of the lesson. The teacher (one of the researchers who implemented the study) asked students to guess what is inside the mystery box. Once the students guessed a correct object, that object would be taken out of the box and shown to class to demonstrate the topics of the day. Cliff hanger questions were motive questions related to the physics concepts given at the end of the session which served as challenge questions for the students for the next day. Accent day activity is a group activity where the class was divided into four. Each group used a specific accent or local dialect which they utilized to deliver a report on power generation, transmission, and distribution.

Attention-catching activities - Breathing and voice activities dominated this cognitive fitness activity. In breathing, students did deep breathing and shhhh tasks. Students were asked to stand or remained seated while performing these activities taking the seat works in their physics class. Students also did the changing voice and callback activities. Changing voice was done by changing the volume of the voice to emphasize concepts in physics during class discussion and callbacks activity, was done by repeating specific words or concepts during the discussion. In addition, students posted strips of words or concepts on board after the repetition of concepts.

Student-energizing activities - The students experienced circle game activity in the form of "What are you 
Effects of cognitive fitness classroom on students' physics achievement and integrated science process skills

doing activity" to show real life examples of projectiles through actions without words. Grouped in two's or three's forming a big circle around the classroom, the game started with the first group doing an action like shooting a ball. Then, the second group asked the first group, "What are you doing?" Consequently, the first group answered, "We are playing golf." The moment the first group mentioned the activity related to projectile, the second group did the action of playing golf. The cycle persisted until the last group did the actions which are related to projectiles.

Mime time directed the silence activity where each group of students categorized into seven groups delivered the concepts related to heat, work, and efficiency without words or sounds. The teacher-researcher allotted time for student to practice their actions for selected words for easy delivery of their assigned concepts. The mime time activity is like a charade game where each group must guess the concepts within the allotted time (5 minutes). One group member wrote the concepts on board while the rest of the groupmates delivered the concepts through actions without creating any words or sounds. The group who guessed fastest wins.

Team/community building activities - Alphabet find dominated the group challenges activity where students wrote complete concepts related to physics using the letters of the alphabet as the initial letters to start the concept or sentence. This task is a timed-activity where students are challenged to do the tasks as fast as they can.

Just for fun activity was done through joke time. Students prepared three types of jokes related to physics concepts as their assignment. Jokes were classified in boxes as pick-up line joke, knock-knock, who's there joke, and free style jokes. Students delivered these jokes in class through draw lots. Some students delivered their jokes personally and some were delivered by the teacher before or during the class hours.

Journal logs, interviews, and anecdotes deduced students' perceptions on all the cognitive fitness classroom activities. The researchers conducted validation and reliability test to all instruments. Accordingly, the experts' evaluated these as content valid and appropriate for its intentions. All students wrote journals for each customized cognitive fitness classroom activities and ten selected students participated in the interviews. Anecdotes described the students' performance in seat works, quizzes, attitude, and behavior during implementation of customized cognitive fitness classroom activities. Results were recorded and captured through video and voice recording. The researchers ensured confidentiality of responses by tagging students with numbers. Likewise, the study only included participants with approved parents' consent. Additionally, the researchers communicated in a general correspondence as noted in the first part of the instrument. This process maintained confidentiality, consent, and ethical standards as prescribed and approved by the research ethics board of the University.

\subsection{Data Analysis}

For the first stage of the study, consolidated descriptive evaluation by experts directed the revision of the instruments of the study. For the second stage, t-test for paired samples compared the pre-test and post-test means of achievement test and integrated science process skills. Transcribing, coding, and thematizing analysed all qualitative data deduced from interviews, journal logs, and anecdotes.

\section{Results and Discussion}

\subsection{Student Achievement in Physics}

In the study, students' test score gains in the pre-test and post-test in the achievement test in physics measured the students' physics achievement as shown in Table 3. 
Chan, J. R., \& Morales, M. P. E.

Table 3

Comparing the pre and post-test (paired difference t-test)- achievement in Physics

\begin{tabular}{|c|c|c|c|c|c|c|}
\hline \multirow{2}{*}{$\begin{array}{l}\text { Learning Content } \\
\text { (DepEd, 2013) } \\
\text { and Cognitive Fitness }\end{array}$} & \multirow{2}{*}{$\begin{array}{c}\text { Brain-based } \\
\text { Learning Principle } \\
\text { (Aparna, 2014) }\end{array}$} & \multicolumn{2}{|c|}{ Mean } & \multicolumn{2}{|c|}{ SD } & \multirow[b]{2}{*}{$p$-value } \\
\hline & & $\begin{array}{l}\text { Pre } \\
\text { test }\end{array}$ & Post test & $\begin{array}{l}\text { Pre } \\
\text { test }\end{array}$ & Post test & \\
\hline $\begin{array}{l}\text { Environment-energizing } \\
\text { (Musical Moments) } \\
\text { Projectile motion } \\
\text { Impulse and momentum } \\
\text { Mechanical energy and } \\
\text { conservation } \\
\text { Heat and temperature }\end{array}$ & $\begin{array}{l}\text { Emotions affect } \\
\text { schema }\end{array}$ & 9.86 & 12.48 & 2.84 & 3.53 & $0.0001^{*}$ \\
\hline $\begin{array}{l}\text { Environment-energizing } \\
\text { (Novelty and Surprise) } \\
\text { Projectile motion } \\
\text { Impulse and momentum } \\
\text { Power generation, transmission } \\
\text { and distribution } \\
\text { Heat and temperature }\end{array}$ & $\begin{array}{l}\text { Challenge enriches } \\
\text { learning while } \\
\text { threat inhibits } \\
\text { learning }\end{array}$ & 10.68 & 12.53 & 3.14 & 3.43 & $0.005^{*}$ \\
\hline $\begin{array}{l}\text { Attention catching } \\
\text { (Breathing activity) } \\
\text { Projectile motion } \\
\text { Mechanical energy and } \\
\text { conservation } \\
\text { Heat and temperature } \\
\end{array}$ & $\begin{array}{l}\text { The whole } \\
\text { physiology of the } \\
\text { brain is engaged in } \\
\text { learning. }\end{array}$ & 9.86 & 12.48 & 2.84 & 3.53 & $0.0001 *$ \\
\hline $\begin{array}{l}\text { Attention-catching } \\
\text { (Voice) } \\
\text { Mechanical energy and } \\
\text { conservation } \\
\text { Heat and temperature }\end{array}$ & $\begin{array}{l}\text { Focused attention } \\
\text { and peripheral } \\
\text { perception are } \\
\text { involved in } \\
\text { learning. }\end{array}$ & 5.39 & 6.53 & 2.19 & 2.039 & $0.008 *$ \\
\hline $\begin{array}{l}\text { Student-energizing } \\
\text { (Circle Games) } \\
\text { Projectile motion }\end{array}$ & $\begin{array}{l}\text { Understanding is } \\
\text { maximized when } \\
\text { facts are infused } \\
\text { naturally in spatial } \\
\text { memory }\end{array}$ & 2.69 & 3.53 & 1.12 & 1.86 & $0.01 *$ \\
\hline $\begin{array}{l}\text { Student-energizing } \\
\text { (Silence) } \\
\text { Heat and Temperature }\end{array}$ & $\begin{array}{l}\text { The brain is a } \\
\text { multi-functional } \\
\text { processor. }\end{array}$ & 2.69 & 2.72 & 1.68 & 1.35 & 0.92 \\
\hline $\begin{array}{l}\text { Team/community building } \\
\text { (Group challenge) } \\
\text { Power generation, transmission } \\
\text { and distribution }\end{array}$ & $\begin{array}{l}\text { The search for } \\
\text { meaning is natural }\end{array}$ & 3.46 & 3.86 & 1.369 & 1.83 & 0.19 \\
\hline $\begin{array}{l}\text { Team/community building } \\
\text { (Just for Fun) } \\
\text { Impulse and Momentum } \\
\text { Mechanical energy and } \\
\text { conservation } \\
\text { Heat and Temperature }\end{array}$ & $\begin{array}{l}\text { Challenge enriches } \\
\text { learning while } \\
\text { threat inhibits } \\
\text { learning. }\end{array}$ & 7.16 & 8.95 & 2.59 & 2.59 & $0.002 *$ \\
\hline
\end{tabular}

The customized cognitive fitness classroom activities such as: Environment-energizing (musical moments, novelty and surprise); attention-catching (breathing and voice); student-energizing (circle games); and team/community building (just for fun) provided statistically significant differences in students' physics achievement. These results suggest that playing music in class; engaging students to unusual, entertaining, and challenging activities; breathing exercises; relating real life application of lessons through games; and integrating physics concepts in delivering a joke in between class and students' tasks improved student achievement in 
Effects of cognitive fitness classroom on students' physics achievement and integrated science process skills

topics: projectile motion, impulse and momentum, mechanical energy and conservation, heat and temperature, and power generation, transmission, and distribution. Specifically, each of the aforementioned cognitive activities anchor to the basic brain-based learning principles (Aparna, 2014) that may have primarily directed brain conditioning for better assimilation and accommodation (Wadsworth, 1996). This scheme includes the cognitive and multiple intelligence aspects that may impact learning by grounding on several intelligence and learning domains. For instance, literature (Caine, 2000; Caine et al., 2009; Pessoa, 2013; Salvkin, 2004; Wagmeister \& Shifrin, 2000; Wolfe, 2001) correlated emotion with cognition where music and games may trigger the neurotransmitter dopamine (DA) - a chemical content that deals with focus, motivation and memory (Bromberg-Martin, Matsumoto, \& Hikosaka, 2010). In fact, Evanski (2009) mentioned that music can improve conditions for optimal learning by enhancing blood flow to areas of the brain responsible for arousal, emotion, reward, and motivation. Additionally, Caine, Caine, MacClintic, and Klimek (2009) reported that engaging students to activities that involve fun and excitement will focus their attention. Thus, the nature of customized cognitive fitness classroom activities proves Jensen's (2008) report that advancement of learning happens quickly when learning environment permits and encourages balance in activities that involve challenge and stress.

However, silence as student-energizing and group challenges as team building activity detected a non-statistically significant mean difference. It can be inferred that certain brain-based learning approaches, specifically, cognitive fitness activities may not suit this specific group of millennials and their learning patterns and styles. In fact, this result negates the reports of Slavkin (2004) and Erlauer (2003) who suggested that collaborative learning provides the brain with the means to explore new information, typically, in a problem solving situation. It may be that Philippine culture and ethnicity of the students affect this result.

\subsection{Integrated Science Process Skills}

Students' test score gain in the pre-test and post-test on the standard Integrated Science Process Skills (ISPS) test measured their improvement in assimilating integrated science process skills as shown in Table 4.

\section{Table 4}

Comparing the pre-test and post-test (paired difference t-test) - achievement in integrated science process skills

\begin{tabular}{|c|c|c|c|c|c|c|}
\hline \multirow{2}{*}{$\begin{array}{c}\text { Cognitive Fitness Activities } \\
\text { (Evanski,2 008) and Integrated } \\
\text { Science Process Skills }\end{array}$} & \multirow{2}{*}{$\begin{array}{l}\text { Brain-based } \\
\text { Learning } \\
\text { Principle } \\
\text { (Aparna, } \\
\text { 2014) } \\
\end{array}$} & \multicolumn{2}{|c|}{ Mean } & \multicolumn{2}{|c|}{ SD } & \multirow[b]{2}{*}{$p$-value } \\
\hline & & Pre test & Post test & Pre test & Post test & \\
\hline $\begin{array}{l}\text { Environment-Energizing (Musical } \\
\text { Moments) } \\
\text { Identifying variables } \\
\text { Defining variables operationally } \\
\text { Describing relationships between } \\
\text { variables }\end{array}$ & $\begin{array}{l}\text { Emotions } \\
\text { affect schema }\end{array}$ & 9.26 & 10.91 & 2.85 & 3.41 & $0.0007 *$ \\
\hline $\begin{array}{l}\text { Environment-Energizing (Novelty } \\
\text { and Surprise) } \\
\text { Defining variables operationally } \\
\text { Describing relationships between } \\
\text { variables }\end{array}$ & $\begin{array}{l}\text { Challenge } \\
\text { enriches } \\
\text { learning while } \\
\text { threat inhibits } \\
\text { learning }\end{array}$ & 4.79 & 5.56 & 1.78 & 1.84 & $0.003^{*}$ \\
\hline $\begin{array}{l}\text { Attention-catching (Breathing } \\
\text { Activity) } \\
\text { Formulating hypothesis } \\
\text { Identifying variables } \\
\text { Defining variables operationally } \\
\text { Designing investigations } \\
\text { Organizing data in tables and graphs }\end{array}$ & $\begin{array}{l}\text { The whole } \\
\text { physiology of } \\
\text { the brain is } \\
\text { engaged in } \\
\text { learning. }\end{array}$ & 13.74 & 16.33 & 3.89 & 4.86 & $0.00002 *$ \\
\hline
\end{tabular}


Table 4 ... continued

\begin{tabular}{|c|c|c|c|c|c|c|}
\hline $\begin{array}{l}\text { Attention-catching (Voice) } \\
\text { Formulating hypothesis } \\
\text { Defining variables operationally } \\
\text { Describing relationships between } \\
\text { variables } \\
\text { Designing investigations }\end{array}$ & $\begin{array}{l}\text { Focused } \\
\text { attention and } \\
\text { peripheral } \\
\text { perception are } \\
\text { involved in } \\
\text { learning. }\end{array}$ & 9.63 & 11.41 & 3.34 & 3.45 & $0.00004 *$ \\
\hline $\begin{array}{l}\text { Student-energizing (Circle games) } \\
\text { Identifying variables }\end{array}$ & $\begin{array}{l}\text { Understanding } \\
\text { is maximized } \\
\text { when facts are } \\
\text { infused } \\
\text { naturally in } \\
\text { spatial } \\
\text { memory }\end{array}$ & 4.81 & 5.72 & 2.29 & 2.58 & $0.03 *$ \\
\hline $\begin{array}{l}\text { Student-energizing (Silence) } \\
\text { Organizing data in tables and graphs }\end{array}$ & $\begin{array}{l}\text { The brain is a } \\
\text { multi-function } \\
\text { al processor }\end{array}$ & 1.21 & 1.37 & .77 & .72 & 0.21 \\
\hline $\begin{array}{l}\text { Team/Community building } \\
\text { (Group challenges) } \\
\text { Describing relationships between } \\
\text { variables }\end{array}$ & $\begin{array}{l}\text { The search for } \\
\text { meaning is } \\
\text { natural }\end{array}$ & 1.91 & 2.18 & .89 & .88 & $0.04 *$ \\
\hline $\begin{array}{l}\text { Team/Community building } \\
\text { (Just for Fun) } \\
\text { Formulating hypothesis } \\
\text { Defining variables operationally } \\
\text { Designing investigations } \\
\text { Organizing data in tables and graphs }\end{array}$ & $\begin{array}{l}\text { Challenge } \\
\text { enriches } \\
\text { learning while } \\
\text { threat inhibits } \\
\text { learning. }\end{array}$ & 8.93 & 10.60 & 3.09 & 3.34 & $0.00003 *$ \\
\hline
\end{tabular}
Note. *significant @ $p<.05$

Customized cognitive fitness classroom activities such as: Environment-energizing (musical moments, novelty and surprise); attention-catching (breathing and voice); student-energizing (circle games); and team/community building (group challenges and just for fun) revealed statistically significant differences in the performance of students in integrated science process skills. It can be inferred that the customized cognitive fitness classroom activities may have improved students' integrated science process skills such as identifying variables, describing relationships between variables, formulating hypothesis, defining variables operationally, designing investigations, and organizing data in tables and graphs. Activities that provided highly significant mean differences included musical moments, novelty and surprise, breathing activity, voice and just for fun. As noted, breathing, voice and just for fun activities significantly improved ISPS of students particularly designing investigations and organizing data. This result may suggest that the aforementioned activities afforded the learners a suited environment for creativity to set in, thus, improving students' design and organization skills. Probably, learners may have attributed these activities (voice, breathing and just for fun) to play activities, which are claimed by Einstein as the highest form of research that enhances learners' creative intelligence (Caine, 1995).

Similar to their physics achievement, the activity "silence" provided a non-statistically significant mean difference. It may be inferred that learners view "silence activity" as something that reminds them of a "negative feeling or emotion" that inhibits learning (Caine et al., 2005; Caulfield et al., 2000; Slavkin, 2004; Wagmeister \& Shifrin, 2000; Wolfe, 2001).

\subsection{Students' perception on the use of customized cognitive fitness classroom activities}

Transcribed, coded, and thematized qualitative data deduced from students' journal logs, interviews, anecdotes and videos determined the students' perception on the use of cognitive fitness classroom activities as presented in Table 5 . 
Effects of cognitive fitness classroom on students' physics achievement and integrated science process skills

Table 5

Students' perception on the use of customized cognitive fitness classroom activities

\begin{tabular}{|c|c|c|c|c|c|c|c|c|}
\hline \multirow[b]{2}{*}{ Themes } & \multicolumn{2}{|c|}{$\begin{array}{c}\text { Environment-energizing } \\
\text { Activities } \\
\end{array}$} & \multicolumn{2}{|c|}{$\begin{array}{c}\text { Attention-catching } \\
\text { Activities } \\
\end{array}$} & \multicolumn{2}{|c|}{$\begin{array}{c}\text { Student-energizing } \\
\text { Activities }\end{array}$} & \multicolumn{2}{|c|}{$\begin{array}{l}\text { Team/ Community } \\
\text { Building Activities }\end{array}$} \\
\hline & $\begin{array}{l}\text { Musical } \\
\text { Moments }\end{array}$ & $\begin{array}{l}\text { Novelty } \\
\text { and } \\
\text { Surprise }\end{array}$ & Breathing & $\begin{array}{l}\text { Voice } \\
(\mathrm{N}=38)\end{array}$ & $\begin{array}{l}\text { Circle } \\
\text { Games }\end{array}$ & Silence & $\begin{array}{l}\text { Getting to } \\
\text { Know/ } \\
\text { Group } \\
\text { Challenges }\end{array}$ & $\begin{array}{l}\text { Just for } \\
\text { Fun }\end{array}$ \\
\hline$* \mathrm{~N}$ & 39 & 39 & 40 & 38 & 41 & 43 & 40 & 39 \\
\hline Relaxed & $\begin{array}{c}14 \\
(36 \%)\end{array}$ & & $\begin{array}{c}28 \\
(70 \%)\end{array}$ & & & & & \\
\hline Focused & $\begin{array}{c}14 \\
(36 \%)\end{array}$ & $\begin{array}{c}36 \\
(92 \%)\end{array}$ & $\begin{array}{c}6 \\
(15 \%)\end{array}$ & $\begin{array}{c}37 \\
(97 \%)\end{array}$ & $\begin{array}{c}16 \\
(39 \%)\end{array}$ & $\begin{array}{c}43 \\
(100 \%)\end{array}$ & $\begin{array}{c}40 \\
(100 \%)\end{array}$ & $\begin{array}{c}33 \\
(85 \%)\end{array}$ \\
\hline Distracted & $\begin{array}{c}7 \\
(18 \%)\end{array}$ & $\begin{array}{c}1 \\
(3 \%)\end{array}$ & $\begin{array}{c}3 \\
(8 \%)\end{array}$ & $\begin{array}{c}1 \\
(3 \%)\end{array}$ & & & & \\
\hline No effect & $\begin{array}{c}4 \\
(10 \%)\end{array}$ & & $\begin{array}{c}3 \\
(8 \%)\end{array}$ & & & & & $\begin{array}{c}6 \\
(15 \%)\end{array}$ \\
\hline Reflective & & $\begin{array}{c}2 \\
(5 \%)\end{array}$ & & & & & & \\
\hline Assimilative & & & & & $\begin{array}{c}25 \\
(61 \%)\end{array}$ & & & \\
\hline
\end{tabular}

The aforementioned procedure generated six major themes of student perceptions: relaxed, focused, reflective, assimilative, no effect, and distracted. Furthermore, the majority of students feel relaxed, focused, and reflective with environment-energizing activities (musical moments and novelty and surprise). Additionally, most of these students feel relaxed and focused when the lesson integrated attention-catching activities such as breathing and voice. Apparently, students also perceive student-energizing activities (circle games and silence) to help them become focused and assimilative while utilizing team/community building activities (group challenges and just for fun) only made them become focused on lesson development. Collectively, students perceived positive feelings of being relaxed and focused, which may be identified as a probable reason for the significant improvement in physics achievement and integrated science process skills. These activities coerced students' neurotransmitter dopamine (DA) to create neural pathways to trigger their brains to be more receptive of new information (Caine et al., 2005). In fact, researchers (Caine et al., 2005; Caulfield et al., 2000; Slavkin, 2004; Wagmeister \& Shifrin, 2000; Wolfe, 2001) believed that positive emotions as perceived by students using the cognitive fitness activities drives their internal system that triggers learning, memory and every other things these students do.

Note however, that few students find these activities: musical moments (18\%), novelty and surprise (3\%), breathing $(8 \%)$, voice $(3 \%)$, and just for fun $(15 \%)$ as either distractive or have no effect on students' current perceptions. It may be that the sound played during their lessons or class activity does not suit their preferences. For example, Adriano and DiPaola (2010) found that most students preferred pop, rock, soul, and rap music and strongly disliked opera, folk, and classical music. Maybe some students perceive breathing (deep breathing and "shhh...") as something that reminds them of negative emotions and they probably don't recognize jokes as something that is good for them in learning. For these students, they capsulize learning as learning and playing as playing with a marked distinction and border. This inference negates initial reports of researchers (Caine et al., 2005; Caulfield et al., 2000; Slavkin, 2004; Wagmeister \& Shifrin, 2000; Wolfe, 2001) that positive emotions and a fear-free environment promotes learning. Consequently, the results suggested that one aspect to look into may be in the area of cultural and background inclination of Filipinos.

\section{Conclusion and Recommendations}

Intentions to define and improve students' physics achievement and integrated process skills thrived in the research arena for decades. In this era where teachers and schools look after digital natives, learning and learning 
patterns may differ a lot compared with how it was decades ago. Thus, efforts to attune to their learning pattern drove researchers to consider brain-compatible approaches to learning. Apparently, this study captured cognitive fitness as a probable way to improve millennials learning schema by making the brain fit to better accommodate and assimilate new learning. Specifically, the majority of customized cognitive fitness activities integrated in physics classes significantly improved students' physics achievement and their integrated science process skills. Students even perceived the integration of such activities as something that brought in them positive emotions such as being focused, relaxed, assimilative, and reflective. These deduced thematic perceptions of students matched the abovementioned literature that may have touched all aspects of the brain keys: 1) go for emotion; 2) give learners choices; 3) novelty water up the brain; 4) teach across senses; 5) brain needs a challenge; 6) praise effort; and 7) personalize. These attributes of the customized cognitive fitness activities may have contributed significantly to the good perception of using or integrating them in physics classes and lessons.

However, certain activities did not provide significant contribution to the improvement of achievement and science process skills of the students. They even perceive such activities as something that is either bringing no effect at all in learning, worse distracting learning. Apparently, these perceptions may have been influenced by the background orientation, family tradition, practices, and beliefs systems. Culturally, these students may have a different perception of "silence and shhhh tasks" that brought in different way of looking at these activities. Seemingly, cultural background and the students' community and communication (which are now part of the six C' of the $21^{\text {st }}$ century learning skills [Global Education and Training (GET), 2016]) may also influence the kind of cognitive fitness activities fit for them, thus, future research might be done along with this line to better customized cognitive fitness activities for Filipinos. This scheme may better improve their achievement and science process skills, necessary to enhance their scientific literacy skills to provide them better chances of success as $21^{\text {st }}$ century learners.

These results may have implications in the pre-service and in-service training of teachers. Teacher education institutions and other education agencies such as the Department of Education (DepEd) and the Commission on Higher Education (CHED) may look into the pre-service curricular reforms accommodating brain-compatible strategies applicable to Filipino learners. Likewise, in-service professional development may integrate trainings on brain-based approaches and customized to the different subject areas across the levels of learning. Brain-influenced pattern of learning may also be the focus of all the units: school administration, guidance unit, service units such as socio-cultural and medical services of an institution in providing a well-balanced and brain-appropriate learning environment for the Filipino learners for more meaningful learning of would be $21^{\text {st }}$ century -skilled Filipinos.

\section{References}

Adriano, J., \& DiPaolo, T. (2010). Teenagers' reasons for listening to music and the students' perception of the effects of listening when completing school assignments. Retrieved from http://scholarsarchive.jwu.edu/cgi/viewcontent.cgi?article $=1000 \&$ context $=\mathrm{k} 12$ ed

Akyurek, E. (2013). Effects of brain-based learning approach on students' motivation and attitudes levels in science class. Mevlana International Journal of Education (MIJE), 3(1), 104-119. http://dx.doi.org/10.13054/mije.13.08.3.1

Anderson, R. (2002). Reforming science teaching: What research says about inquiry? Journal of Science Teacher Education, 13(1), 1-12. http://dx.doi.org/10.1023/A:1015171124982

Aparna, M., \& Smita, P. (2014). Fostering student creativity using brain-based learning. Scholarly Research Journal for Humanity Science \& English Language, 1/4, 549-560.

Asian Development Bank (ADB). (2014). ASEAN 2030 Toward a Borderless Economic Community. Retrieved from

https://www.adb.org/sites/default/files/publication/159312/adbi-asean-2030-borderless-economic-comm unity.pdf

Australian Council for Educational Research. (2014). Retrieved from https://www.acer.edu.au/ 
Effects of cognitive fitness classroom on students' physics achievement and integrated science process skills

Bas, G. (2010). Effects of brain-based learning on students' achievement levels and attitudes towards English lesson. Retrieved from

http://web.b.ebscohost.com/ehost/pdfviewer/pdfviewer?Sid=e4575233-5cde-4ba2-bcba-ddcc17cabb2c

$\% 40$ sessionmgr115\&vid=33\&hid=125

Baser, M., \& Durmus, S. (2010). The effectiveness of computer supported versus real laboratory inquiry learning environments on the understanding of direct current electricity among pre-service elementary school teachers. Eurasia Journal of Mathematics, Science \& Technology, 6(1), 47-61.

BouJaoude, S. (2002). Balance of scientific literacy themes in science curricula: the case of Lebanon. International Journal of Science Education. 24(2), 139-156. http://dx.doi.org/10.1080/09500690110066494

Bromberg-Martin, E.S., Matsumoto M., \& Hikosaka, O. (2010). Distinct tonic and phasic anticipatory activity in lateral habenula and dopamine neurons. Neuron, 67, 144-155.

http://dx.doi.org/10.1016/j.neuron.2010.06.016

Caine, G., Caine, R.N., McClintic, C., \& Klimek, K. (2005). 12 Brain/Mind learning principles in action. Thousand Oaks, CA: Corwin Press.

Caine, R., \& Caine, G. (1995) “Reinventing schools through Brain Based Learning." Educational Leadership, 52(7), 43-47.

Caine, R., \& Caine, G. (2000). How the brain learns in ecoliteracy: Mapping the domain. Center for Ecoliteracy.

Caine, R., Caine G., McClintic, C., \& Klimek, K. (2009). 12 Brain/Mind learning principles in action developing executive functions of the human brain. United States of America: Corwin Press.

Caulfield, J., Kidd, S., \& Kocher, T. (2000). Brain-based instruction in action. Educational Leadership, 58(3), 62-65.

Cheng, T. (2016). Can growth mindset really grow your brain. Retrieved from https://www.learningandthebrain.com/blog/growth-mindset/

Cohen, J. (2006). Social, emotional, ethical and academic education: Creating a climate for learning, participation in democracy and well-being. Harvard Educational Review, 76(2), 201-237. http://dx.doi.org/10.17763/haer.76.2.j44854x1524644vn

Cunningham, J. (2012). Student achievement. Retrieved from http://www.ncsl.org/documents/educ/CharterSchool StudentAchievement.pdf

Dela Cruz, J. P. C. (2015). Development of an experimental science module to improve middle school students' integrated science process skills. Retrieved from

http://www.dlsu.edu.ph/conferences/dlsu_research_congress/2015/proceedings/LLI/018LLI_DelaCruz JP.pdf

Duman, B. (2010). The effects of brain-based learning on the academic achievement of students with different learning styles. Retrieved from http://web.b.ebscohost.com/ehost/pdfviewer/pdfviewer?sid=e4575233-5cde-4ba2-bcba-ddcc17cabb2c\% 40sessionmgr115\&vid=20\&hid=125

Dweck, C. S. (2006). Mindset. New York, NY: Random House.

Erlauer, L. (2003). The brain-compatible classroom: using what we know about ;earning to improve teaching. Alexandria, Virginia: Association for Supervision and Curriculum Development.

Evanski, J. (2009). Classroom activators. United States of America: Corwin Press.

Fensham, P. J. (1985). Science for all. Journal of Curriculum Studies, 17, 415-435. http://dx.doi.org/10.1080/0022027850170407

Gilkey, R., \& Kilts, C. (2007). Cognitive fitness. Harvard Business Review.

Gilkey, R., \& Kilts, C. (2007). Managing yourself Cognitive fitness. Harvard Business Review. Retrieved from http://www.getinsidehealth.com/PageFiles/478/Cognitive\%20fitnessR0711Bf2.pdf

Global Education and Training (GET). (2016). Retrieved from http://getkh.com/

Gozuyesil, E., \& Dikici, A. (2014). The effect of brain based learning on academic achievement: a meta-analytical study (Thesis). Niğde University.

Hazen, R. (2002). Why should you be scientifically literate? Action Bioscience, Retrieved from 
Chan, J. R., \& Morales, M. P. E.

http://www.actionbioscience.org/newfrontiers/hazen.html?print

Hobson, A. (2006). Science literacy and backward priorities. Physics Teacher, 44, 488-489. http://dx.doi.org/10.1119/1.2362936

Hussain, M., \& Akhtar, M. (2013). Impact of hands-on activities on students' achievement in science: An experimental evidence from Pakistan. Middle-East Journal of Scientific Research, 16 (5), 626-632.

Jensen, E. P. (2008). Brain-based learning the new paradigm of teaching second edition. Newbury Park, CA: Corwin Press.

Kamisah, O., \& Neelavany, M. (2010). Setting new learning targets for the 21 st century science education in Malaysia. Procedia Social and Behavioral Science, 2, 3737-33741. http://dx.doi.org/10.1016/j.sbspro.2010.03.581

Labriole, M. (2010). Promoting brain-science literacy in the K-12 Classroom. Retrieved from http://dana.org/Cerebrum/2010/Promoting_Brain-Science_Literacy_in the_K-12_Classroom/

Lancour, K. L. (2008). Bio--process lab supervisor and coaches guide. Retrieved from http://scioly.org/wiki/images/d/d6/Pslsl_training_hammond04.pdf

Narmadha, U., \& Charmundeswari S. (2013). Attitude towards learning of science and academic achievement in science among students at the secondary level. Journal of Sociological Research, 4(2), 1948-5468. http://dx.doi.org/10.5296/jsr.v4i2.3910

National Association for Research in Science Teaching (NARST) (1990). Research matters - to the science teachers. NARST: Publications. Retrieved from https://www.narst.org/publications/research/skill.cfm

National Monitoring Study of Student Achievement (NMSSA). (2012). Science 2012. Educational assessment research unit and New Zealand council for educational research.

NCREL \& Metiri. (2003). Engauge® 21st century skills: Literacy in digital age. Napierville, IL \& Los Angeles, CA: NCREL \& Metiri.

NCREL. (2003). Engauge ${ }^{\circledR} 21$ st century skills: Literacy in the digital age. Retrieved from http://www.grrec.ky.gov/SLC_grant/engauge21st_Century_Skills.pdf

Özdem, Y., Çavaú, P., \& Çavaú, B. (2010). An investigation of elementary students's scientific literacy levels. Journal of Baltic Science Education, 9(1), 1648-3898.

Ozgelen, S. (2012). Students' science process skills within a cognitive domain framework. Eurasia Journal of Mathematics, Science \& Technology Education. Retrieved from http://www.ejmste.com/v8n4/eurasia_v8n4_ozgelen.pdf http://dx.doi.org/10.12973/eurasia.2012.846a

Pessoa, L. (2013). The cognitive emotional brain: From interactions to integration. MIT Press. http://dx.doi.org/10.7551/mitpress/9780262019569.001.0001

Raj, G. R., \& Devi, N. S. (2014). Science process skills and achievement in science among high school students. Scholarly Research Journal for Interdisciplinary Studies, 2(15), 2435-2443.

Ramakrishnan, J., \& Annakodi, R. (2013). Brain-based learning strategies. International Journal of Innovative Research \& Studies, 2(5), 235-242.

Research and Development (RAND) Education. (2012). Teachers matter: Understanding teachers' impact on student achievement. Retrieved from http://www.rand.org/content/dam/rand/pubs/corporate_pubs/2012/RAND_CP693z1-2012-09.pdf

Rouman, M. (2016). Learning, brain \& cognitive fitness understanding how the brain learns, functions and stays healthy. Retrieved from http://www.scoop.it/t/learning-brain-cognitive-fitness.html

Saleh, S. (2012). The effectiveness of the brain based teaching approach in enhancing scientific understanding of Newtonian physics among form four students. International Journal of Environmental \& Science Education, 7(1), 107-122.

Shive, L. E. (2002). Integrated Process Skills Test II. Instrument 3. Retrieved from http://www.lifescied.org/content/suppl/2009/04/16/5.3.218.DC1/3_TIPSII.pdf

Simmonds, A. (2014). How neuroscience is affecting education: Report of teacher and parent surveys. Retrieved from

http://www.wellcome.ac.uk/stellent/groups/corporatesite/@msh_peda/documents/web_document/WTP 055240.pdf 
Effects of cognitive fitness classroom on students' physics achievement and integrated science process skills

Slavkin, M. (2004). Authentic learning: How learning about the brain can shape the development of students. Lanham, MD: Scarecrow Education.

Steinmayr, R., Meißner A., Weidinger, A. F., \& Wirthwein, L. (2015). Oxford Bibliographies. Retrieved from http://www.oxfordbibliographies.com/view/document/obo-9780199756810/obo-9780199756810-0108. $\underline{\mathrm{xml}}$

Tan, M. (2004). Nurturing scientific and technological literacy through environmental education. Journal of International Cooperation in Education, 7(1), 115-131.

Taylor, J. A., Scotter, P. V., \& Coulson, D. (2007). Bridging research on learning and student achievement: the role of instructional materials. Science Educator, 16(2), 44-45.

The DANA Alliance for brain initiatives. (2008). Your brain at work. USA.

Tüfekçial, S., \& Demirelb, M. (2009). The effect of brain based learning on achievement, retention, attitude and learning process. Procedia - Social and Behavioral Sciences, 1(1), 1782-1791. http://dx.doi.org/10.1016/j.sbspro.2009.01.316

Turiman, P., Omar, J., Daud, A. M., \& Osman, K. (2011). Fostering the $21^{\text {st }}$ century skills through scientific literacy and science process skills. Procedia - Social and Behavioral Sciences, 59(17), 110-116.

Wadsworth, B. J. (1996). Piagets theory of cognitive and affective development $\left(5^{\text {th }}\right.$ ed.). New York: Longman.

Wagmeister, J., \& Shifrin, B. (2000). Thinking differently, learning differently. Educational Leadership, 58(3), $45-48$.

Wolfe, P. (2001). Brain matters: Translating research into classroom practice. VA: ASCD, Alexandria. 
Chan, J. R., \& Morales, M. P. E. 